\title{
COMMUNITY PARTICIPATION: A NEW DEVELOPMENT IN EDUCATIONAL MANAGEMENT
}

IBRAHIM BABA FIKA, Ph.D.

\begin{abstract}
Communities can play a varien of roles in the provision and management of education and learning processes. Community comribution to schools can go beyond the traditional financial contribution. It can howerer extend on a broader range of functions which ind ade administrative (swch as school maintenance). managerial asuch as student and reacher discipline). financial (mobilising of fiunds and resonrcess), pedagogical lesfablishing a preschool), persommel (monitoring reacher antendances). The community is responsible for providing a harmonions working condition in school. The focus of the school. teaching methods, the focus of the curriculum as seell as the school discipline are all ultimatels desired firm the community in which the school fincrions. If there is no hamomions and dynamic relationship between the community. and school, education will be pallid, illusive and mable to make any positive impact on the leaners' behavior. It is therefore against this backdrop, that this paper examines commmity participarion and effective school management.
\end{abstract}

\section{Introduction}

Educational management refers to the utilization of available human and material resources to achieve educational goals and objectives (Sheik, 2006). The main focus of educational management therefore, is to harness and marshal resources for the actualization of educational goals and objectives. Superficially, this may be seen as a simple task that could be done by anybody. This perhaps explains why people with any sort of educational background are appointed to manage education. The complexity of the present educational system however, requires a school manager to have the basic conceptual. social and technical knowledge as well as skills and competence relevant in accomplishing educational goals and objectives. Thus, for one to become a school manager he needs to acquire professional and technical know-how of management in addition to personality traits and experience. The era when school managers are appointed based on personal characteristics and experience has gone. School managers should therefore. be appointed based on their professional background and technical know-how. 
The management of educition in Nigeria rests in the hands of a few officials in the ministry of education and schools management boards. These officials map out plans on how education should be managed. In essence this means that only few officials are responsible for the planning and control of educational programmes in Nigeria. The implication of this practice is that other stakeholders hardly make any meaningful contribution towards educational management thus making educational system in the country less effective.

Schools are meant to serve the community in which they are located. In Nigeria today, such schools are alien to the communities they are expected to serve. Parents hardly know the programme and operations of the schools to which they send their children. Basic education is meant to serve the needs and aspirations of the communities in which the schools that provide basic education are located. Such schools are seen by community as government establishments that are solely run by government. The communities as a result of this misperception develop apathy towards school programmes. Consequently. communities place high premium on what the ministry of education can provide rather than on what different units of the society can do to promote education.

\section{Need for community participation}

There is need for community involvement in the management of our educational system. Government alone cannot adequately and effectively manage the education system hence, the need for community participation. This becomes necessary now that Nigeria is trying to implement Universal Basic Education Scheme. As a result of implementing the basic education. more schools are established to cater for the teeming school going- age children. This therefore, calls for a greater need than ever before to involve members of the community in the management of schools. The direct participation of different segments of the community in the development of educational policies, which affect the destiny of their children, is very crucial. It is generally believed that an active and attentive community is likely to ensure effective and efficient performance (Ahmed and Nath 2005). The community can be involved in such policy decisions on curriculum development and modification. provision and maintenance of facilities and recruitment of teachers. The quality and quantity of educational facilities in schools are grossly inadequate 
which ultimately affect the performance of the educational system negatively (Abdul-Rahman. 2011). The author believes that community participation is the best strategy to restore sanity in the educational system. It is the author's strong belief that the involvement of communities in the management of schools will mark a turning point in the improvement of school management in Nigeria.

Fantini (1980), identifies four-point model of community involvement and these are: client-related. producer-related, consumer-related and governor-related.

a. Client-related involvement: In this type of involvement schools see parents and community members as clients who have little knowledge of school programmes and their input is restricted to PTA activities, teachers and parents days, school ceremonies and other scheduled events of the school. In this case parents are not involved in decision-making in schools.

b. Producer-related involvement:

Parents in this type of involvement participate as school volunteers. professional. tutors and assistants. They are always called upon to participate in civic and business school-related programmes. c. Consumer-related involvement: This type of involvement sees parents as active intelligent and informed consumers. The school helps in solving a variety of community problems.

d. Governor-related involvement: Sees parents as active stakeholders in the management of education. It permits them take active role in running the schools. They give advice and recommendations on major school policies.

In Nigeria today, the commonest type of community involvement is that of client related type. This type of involvement, however, does not permit parents to contribute effectively toward education development. Consequently, there is need to have a better and more direct type of community involvement like producer-related and consumer-related types.

\section{School-Community relations for enhanced community participation:}

It is evident today that schools and communities should work hand-inhand with each other for them to actualize their mutual goals. Schoolcommunity relation is therefore, very crucial for the effective management of schools. School-community partnership can bring together many 
resources and strategies to enhance communities that support youth and their families. Communities can therefore, be seen as a critical resource in school management. Often. the community is seen to contribute either financially or in kind to support schools. Communities can however, participate in a much broader range of functions. Such functions could include: administrative (e.g school maintenance), managerial (such as students and teachers discipline), financial (mobilizing funds and resources or personnel (monitoring teacher's attendance) (UNESCO 2006).

There are indeed quite a number of activities in which schools can be involved to improve school-community relations. Below are some of the suggested activities as presented by Combs (2008);

1. Encouraging cornmunity use of school facilities: In must cases school buildings remain empty after the end of normal school day. Encouraging non-profit community groups to use such facilities can cement good relationship between the school and the community in which it is located.

2. Introduction of back to school week: Introducing a school week could also promote better school- community relations. This can be done by choosing a week during the school year to invite parents and community members to the school. The school should make a special effort to personally invite community and business leaders to attend school for the day, or part of the day.

3. Students" recognition: Irıvite students who perform exceptionally well to an honour banquet. Such a banquet can be organized at a local restaurant during schools hours or later in the evening. Such a banquet can raise the morale of such a student thereby promoting productivity.

4. Organizing career day: Organize career days, this is not only good educational experience for the students but it also helps business people learn more about the schools and their needs. It can also help the schools know the employment needs in the area.

5. Honour roll: The school can publish the list of students who excel during the school year in a local media. Teachers and administrators should be encouraged to write to such students in recognition of their outstanding performance. Using a database can make this task easier and can also allow administrators to write special letters to those students whose 
averages increased signilicantly during the year in question.

6. Newsletter: Schools should be able to provide periodic newsletters to the families of students as well as to board members, business leaders and other important community members. A simple database. according to Combs (2008) can be used to include new people. encourage members of the school community to suggest other folks who might be included in the mailing list.

7. Gold cards: Issue students who perform excellently well with Gold cards. Such Gold cards should be sponsored by participating businesses which provide discounts to such students. Some businesses provide reduced prices on items in their stores while others allow students to have something for free.

8. Provision of senior citizen passes: Provide passes to senior citizens in the area to attend all school functions at no charge. Many of such senior citizens will appreciate the extra welcome provided them by the school, thus cementing good relationship between the school and the community. This can pave way for better community participation in the running of the school.
9. Positive re-enforcement: Members of staff should be encouraged to contact families of students by phone or letter when a student shows significant improvement or demonstrates positive qualities of behaviour. School management can further strengthen the rapport with parents by contacting them when a student does something well.

Although the aforementioned activities may not be exhaustive, but they go a long way in ensuring school-community relationship that can serve as good foundation for effective community participation.

\section{Community participation in school management}

Community participation is critical to the successful managements of schools in Nigeria. The implementation of the Universal Basic Education (UBE) may not be successfully done if parents are not involved in the management of schools. The call for community involvement in the management of schools has come from two distinct sources. It emerged from neo-liberal imperatives for more efficient use of financial and material resources on one hand, and increased political advocacy for greater community ownership and involvement in decision-making on the other (Rose, 
2003: Pryor. 2005). It has however been speculated that community participation has been a top-down imposition rather than response to demands from communities for greater involvement (Watt. 2001: Pryor and Ampiah, 2003; Rose 2003).

Despite the fact that community participation has been viewed as topdown imposition. the author believes that the problem of better school management cannot be solved without giving parents the opportunity for involvement in their children's education. Thus, parent's views should be considered on what is to be taught and how to encourage local contributors of ideas, resources and management.

For effective school management, this paper therefore suggests the involvement of community in the following areas:

i. Enrolment to school: The community should be involved in mobilizing pupils/students to be enrolled into schools. The involvement of parents in school management will bring about high enrolment rate more especially in rural areas. This stand point was corroborated by Watt (2001) who argued that increased community participation is crucial in improving their children's enrolment.

The community should also be saddled with the responsibility of monitoring students' attendance so that those enrolled into school are punctual to their classes. Thus, the community can do this by talking to elders of families that do not send their children to school. Developing productive links between the school and the community will go a long way in enhancing school enrolment and attendance

ii. Provision of material resources: the most salient community participation in schools is at the level of providing resources to the schools. Financial contributions to schools most often take the form of fundraising projects or voluntary contributions as well as labour in constructing school buildings (Bray, 2003; Watt. 2001). Critically speaking, looking at the proliferation of schools government alone cannot shoulder the responsibility of providing all schools with the required number of facilities and structures. Thus, the need to involve parents/communities in the provision of such facilities and structures. Parents. involvement in the provision of 
resources to schools according to Watt (2001) will ensure school accountability which will ultimately enhance school management.

iii. School supervision: the parents and community should be ascribed with the responsibility of making schools transparent and accountable to the community. This will create a congenial school environment for effective management. Most of the schools are located within a settlement where most of the students/pupils reside. It is therefore expected that parents and the community can play a crucial role in supervising the closing and opening hours of the school, conduct of the teachers and students, and cleanliness of the school environment.

iv. Monitoring Teachers' activities: Another way that community participation can enhance effective school management is by monitoring teachers' activities. Parents should be watchdogs to ensure that teachers live up to expectations. Some teachers are inherently lazy but if they know that they are being closely watched by the community. this will ginger them to work harder thereby ensuring better performance and effective school management. v. Conflict Resolution: conflict resolution in schools is yet another area that community can be involved in. Parents can be mobilized to be part of a committee that is saddled with the responsibility of resolving conflicts. Religious clerics can be appointed on such a committee so that any conflict that relate to religion can be amicably resolved. It is important to involve the community and the parents in the school management community so that they can vividly understand what is being taught and how. It could also enable the community to understand the significance of those activities carried out in schools. This can assist in forestalling conflicts that may arise as a result of lack of understanding of school activities.

vi. School discipline: This is yet another area that community can play an important role in. Parents are supposed to be on the school disciplinary committee. This will enable the parents have first-hand information on the types of offences committed in schools and proffer solutions on how to overcome such problems. 


\section{Conclusion:}

Community participation. no doubt. plays an important role in effective implementation of school programmes. For school management to be effective therefore. there is need for more collaboration between the school and the community, where both sides become partners in reshaping school policy and decision-making. It is believed that strong parental and community involvement in education policy and decision-making can provide a sound environment to ensure children's higher educational attainments. It is therefore, the author's strong conviction that if parents are fully involved in the management of schools, then such schools may ultimately succeed in attaining their goals. It is however pertinent to note that for community participation to yield the desired results, there is need for changes in the perspectives and attitudes of the people to overcome the inertia of the past and venture to take new initiatives.

\section{References}

Abdui-Rahman, A. K. (2011). Evaluation of Human and Material Resources for National Minimum Standard in Senior Secondary Schools of Borno State, Nigeria. (Unpublished M. Ed. Dissertation. University of Maiduguri).

Ahmed, M. \& Nath, S. (2005). Education Watch Report 2003/4. Quality with Equity: The Primary Education Agenda. Dhaka, Bangladesh: Campaign for Popular Education.

Bray, M. (2003). Community initiatives in education: goals, dimensions and linkages with governments; compare.

Combs, H. J. (2008). Improving School-Community Reìations hicombs@edulink.org

Fantini, M. D. (1980). Community participation: Alternative patterns and their consequences on educational achievement. Paper presented at the annual meeting of the American Research Association. Boston. 
Ostein. A. C. (19:1)1). Decentralization and community participation policy

- of Big school systems. Phi: Deltakappan.

Pryor, J. (2005). Can community participation mobilize social capital for improvement of rural schooling? A case study from Ghana; compare.

Pryor, J. \& Ampiah. J. (2003). Understandings of Education in an African Village: The Impact of ICTs. Education Series Research Report No. 52. London: DfID.

Rose, P. (2003). Community participation in school policy and practice in Malawi: balancing local knowledge. national policies and international priorities; compare.

Sheik, A. M. (2006). Human Resource Development and Management. S. Chand and Company Itd New Delhi.

UNESCO (2006). Community Participation:; International Institute for Educational Planning: Paris

Watt. P. (2001). Community Support for Basic Education in Subsaharan Africa. Africa Region Human Development Working Paper Sieries. Washington, DC: World Bank. 